\title{
Nitric Oxide-dependent Efflux of cGMP in Rat Cerebellar Cortex: An in vivo Microdialysis Study
}

\author{
Dasan Luo, Esther Leung, and Steven R. Vincent \\ Kinsmen Laboratory of Neurological Sciences, Department of Psychiatry, The University of British Columbia, Vancouver, \\ British Columbia V6T 1 Z3 Canada
}

The stimulation of excitatory amino acid receptors in the cerebellar cortex results in the $\mathrm{Ca}^{2+} /$ calmodulin-dependent activation of nitric oxide synthase. This leads to an increase in tissue levels of cGMP following the interaction of nitric oxide with soluble guanylyl cyclase. The cerebellar cortex has the highest levels of nitric oxide synthase and cGMP in the brain; however, the levels of guanylyl cyclase and cGMPphosphodiesterase are remarkably low. Thus, the mechanisms regulating cGMP levels in cerebellar cells are unclear. One report has noted that CGMP can be released from cerebellar slices. We have therefore used intracerebellar microdialysis in awake, freely moving rats to test the hypothesis that activation of nitric oxide synthase in the cerebellar cortex results in the release of cGMP. Climbing fibers, which release excitatory amino acids in the cerebellum, were activated with systemic harmaline. This resulted in an immediate increase in extracellular cGMP, which was blocked by TTX or the removal of extracellular $\mathrm{Ca}^{2+}$, and attenuated by prior lesion of the climbing fibers. Blockade of $\mathrm{N}$-type calcium channels with $\omega$-conotoxin also antagonized the harmaline-induced increase. In contrast, blockade of L-type calcium channels, or inhibition of anion transport with probenecid or bromosulfophthalein, potentiated the increase in cGMP seen in response to harmaline. Inhibitors of nitric oxide synthase or guanylyl cyclase prevented the harmaline-induced increase in extracellular cGMP, while phosphodiesterase inhibitors potentiated the increase. Local application of the NMDA antagonist 2-amino-5-phosphonopentanoic acid or the AMPA receptor antagonist 6-cyano-7-nitroquinoxaline-2,3dione attenuated the effect of harmaline. In the presence of TTX, local application of NMDA, AMPA, or the metabotropic agonist trans-1-amino-1,3-cyclopentane-dicarboxylic acid ( $t$-ACPD) elevated extracellular cGMP. Thus, activation of excitatory amino acid receptors results in a nitric oxidedependent increase in the extracellular levels of cGMP in the cerebellar cortex. This may indicate the presence of an intercellular metabolic pathway for the regulation of intracellular cGMP levels. It is also possible that extracellular cGMP plays a role in intercellular communication in the cerebellar cortex.

\footnotetext{
Received Mar. 8, 1993; revised June 8, 1993; accepted July 6, 1993.

This research was supported by a grant from the Medical Research Council of Canada. S.R.V. is an MRC Scientist.

Correspondence should be addressed to Steven R. Vincent, Ph.D., at the above address.

Copyright $@ 1994$ Society for Neuroscience $0270-6474 / 94 / 140263-09 \$ 05.00 / 0$
}

IKey words: nitric oxide, cGMP, guanylyl cyclase, microdialysis, cerebellar cortex, excitatory amino acids, climbing fibers, harmaline]

Glutamate receptor activation in cerebellar slices has been shown to result in the formation of a diffusible messenger with properties similar to those of the endothelium-derived relaxing factor (Garthwaite et al., 1988). This has now been shown to correspond to nitric oxide (NO), produced by the $\mathrm{Ca}^{2+} /$ calmodulindependent activation of NO synthase (Bredt and Snyder, 1989; Garthwaite et al., 1989). The release of endogenous excitatory amino acids, by activation of the climbing fiber afferents with harmaline, also evokes NO synthesis (Wood et al., 1990). The NO formed binds to and activates soluble guanylyl cyclase, producing an increase in the tissue levels of cGMP. Histochemical and biochemical studies of the cerebellum have indicated that NO is formed in basket and granule cells, from which it diffuses into other target cells containing the guanylyl cyclase (Garthwaite, 1991; Vincent and Hope, 1992). Thus, in this system NO appears to act primarily as an intercellular messenger.

Although the cerebellum has very high levels of NO synthase, and the levels of cGMP in the cerebellum are an order of magnitude higher than in most brain regions, it has only relatively low levels of guanylyl cyclase (Greenberg et al., 1978). The fact that the cGMP phosphodiesterase activity in the cerebellum is the lowest in the brain (Greenberg et al., 1978) may explain the high basal cGMP levels, and the dramatic increases in cGMP levels that can be seen in response to various drugs. These observations suggest enzymatic degradation via phosphodiesterase may not play a major role in regulating intracellular cGMP levels in cerebellar cells. Instead, one in vitro study on cerebellar slices found evidence for the release of cGMP that could be increased by depolarization, glutamate stimulation, or an organic nitroso compound (Tjörnhammar et al., 1986). This suggests that cyclic nucleotide release may be an important feature of the cerebellar cGMP signal transduction system.

Cyclic nucleotides are the classic intracellular second messengers. However, for many years the release of these molecules from various cell types has also been described (Barber and Butcher, 1983). The efflux of cAMP was first noted when pigeon erythrocytes were stimulated by noradrenaline (Davoren and Sutherland, 1963). Shortly thereafter, cAMP release from rabbit cerebellar slices was noted following catecholamine stimulation (Kakiuchi and Rall, 1968). An efflux of cGMP that parallels the increase in tissue levels has since been described in a number of tissues, including the pineal and posterior pituitary (O'Dea et al., 1978), the isolated perfused rat kidney (Burton et al., 
1990; Heuze-Joubert et al., 1992), isolated rat aorta (Schini et al., 1989), bovine aorta endothelial cells (Schini et al., 1988), pancreatic acinar cells (Kapoor and Krishna, 1977), and hepatocytes (Billiar et al., 1992). Furthermore, there is a substantial level of cGMP in the cerebrospinal fluid (CSF) (Trabucchi et al., 1977) and plasma cGMP levels can be influenced by various drug treatments (Brandt and Conrad, 1991; Schuller et al., 1992). In the present study, we have used the technique of in vivo microdialysis to determine whether an efflux of cGMP is associated with the activation of NO production in the cerebellar cortex following excitatory amino acid receptor stimulation.

\section{Materials and Methods}

Microdialysis probes. Transverse microdialysis probes were constructed using a saponified cellulose ester membrane (SCE 135, Cordis Dow Medical B.V., Netherlands). The horizontal probe had an open length of $10 \mathrm{~mm}$ and an outer diameter of $0.27 \mathrm{~mm}$. Stainless steel cannulas were glued to both ends of the dialysis fiber.

Animals and surgery. Adult male Wistar rats (250-300 gm) were anesthetized with pentobarbital and stereotaxically implanted with a transverse microdialysis probe in the cerebellar cortex (interaural, AP $-2.1, \mathrm{DV}-3.5$ ). The stainless steel cannulas were secured with dental cement to three anchoring screws on the top of the skull. The animals were allowed to recover for $48 \mathrm{hr}$ before the experiments.

One group of animals received injections of the climbing fiber toxin 3-acetylpyridine according to the protocol of Llinas et al. (1975) 1 week prior to implantation of the microdialysis probe. The animals received $75 \mathrm{mg} / \mathrm{kg}$ of 3 -acetylpyridine, followed $3 \mathrm{hr}$ later by $15 \mathrm{mg} / \mathrm{kg}$ harmaline, and after another $1.5 \mathrm{hr}$ by $300 \mathrm{mg} / \mathrm{kg}$ niacinamide.

Intracerebellar microdialysis. The microdialysis probes were perfused at $5 \mu \mathrm{l} / \mathrm{min}$ with artificial CSF, which contained $147 \mathrm{~mm} \mathrm{NaCl}, 3.0 \mathrm{mM}$ $\mathrm{KCl}, 1.0 \mathrm{mM} \mathrm{MgCl}, 1.3 \mathrm{mM} \mathrm{CaCl}_{2}, 1 \mathrm{mM} \mathrm{NaPO}_{4}, \mathrm{pH} 7.4$, in awake, freely moving animals. Fractions were collected every $20 \mathrm{~min}$, lyophilized, and stored at $-20^{\circ} \mathrm{C}$ until assayed.

cGMP radioimmunoassay. cGMP was determined by radioimmunoassay (RIA) (New England Nuclear, Dupont) performed using the acetylation procedure for both standards and samples to increase sensitivity. The freeze-dried dialysis samples were reconstituted in RIA buffer and assayed in duplicate. The cGMP RIA had a sensitivity of 1.0 $\mathrm{fmol} / 100 \mu \mathrm{l}$ and an $\mathrm{IC}_{50}$ of $38 \mathrm{fmol} / 100 \mu \mathrm{l}$, and the variation between assays was less than $\pm 5 \%$.

Drugs. The drugs used in this study were obtained from Research Biochemicals Inc., Natick, MA: ( \pm )- $\alpha$-amino-3-hydroxy-5-methylisoxazole-4-propionic acid (AMPA), trans-1-amino-1,3-cyclopentane-dicarboxylic acid ( $t$-ACPD), 2-amino-5-phosphonopentanoic acid (AP5), 6-cyano-7-nitroquinoxaline-2,3-dione (CNQX), w-conotoxin, $\mathrm{N}^{\mathrm{G}}$-monomethyl-L-arginine (L-NMMA), $\mathrm{N}^{\mathrm{G}}$-monomethyl-D-arginine (D-NMMA), $\mathrm{N}^{\mathrm{G}}$-nitro-L-arginine methyl ester hydrochloride (NAME), $\mathrm{N}^{\mathrm{G}}$-nitro-Larginine (N-Arg); from Rhône-Poulenc Rorer Ltd., Dagenham, UK: Zaprinast (M\&B 22948); from Sigma, St. Louis, MO: bromosulfophthalein, harmaline, 3-acetylpyridine, probenecid, 3-isobutyl-1-methyl xanthine (IBMX), nifedipine, tetrodotoxin (TTX); from Calbiochem: LY-83583; and from British Drug House: methylene blue. The drugs were administered either systemically (intraperitoneal injection) or locally via the microdialysis probe. At a flow rate of $5 \mu 1 / \mathrm{min}$, in vitro studies indicated that the concentration of applied drug escaping the microdialysis probe corresponded to approximately $10 \%$ of the applied concentration.

Histology and statistics. After the dialysis experiments, the rats were killed and the brains removed and fixed in 4\% paraformaldehyde. They were then cryoprotected in $15 \%$ sucrose, and $30 \mu \mathrm{m}$ coronal sections through the cerebellum were cut on a cryostat and mounted onto chromealum-coated slides. The sections were stained with cresyl violet and the probe placements were determined. In the 3-acetylpyridine-treated animals, cresyl violet-stained sections through the inferior olive were also examined to estimate the extent of the lesion.

The data are displayed as the percentage of the mean + SEM of the first three baseline samples. At least three animals were tested for each treatment. Analysis of variance (ANOVA) was used to determine whether the CGMP concentrations in dialysates in response to applied drugs differed significantly from the control. A confidence level of $95 \%$ was accepted as significant.
In vitro recovery of cGMP by the microdialysis probes was determined by placing the probe in a beaker containing various concentrations (1.7-45 nM) of cGMP at the standard perfusion rate of $5 \mu \mathrm{l} / \mathrm{min}$. Additional experiments were also done at various flow rates $(1-10 \mu \mathrm{l} /$ $\mathrm{min}$ ). The cGMP concentrations in the dialysate and in the beaker were determined using the same RIA procedure used for the in vivo studies.

\section{Results}

The baseline level of cGMP in the dialysate at a flow rate of 5 $\mu \mathrm{l} / \mathrm{min}$ was $0.74 \pm 0.07 \mathrm{pmol} / \mathrm{ml}(n=65)$. The in vitro recovery rate at $5 \mu \mathrm{l} / \mathrm{min}$ was about $11 \%$, suggesting a basal extracellular cGMP level in the cerebellar cortex of about $6.7 \mathrm{~nm}$. In vitro experiments indicated that the recovery of cGMP varied inversely with the flow rate. In an attempt to determine more accurately the extracellular level of cGMP, animals were perfused overnight at a flow rate of $0.1 \mu \mathrm{l} / \mathrm{min}$. This yielded a concentration of $4 \mathrm{nM}$ in the dialysate, which at a recovery estimated to be $55 \%$ gave a basal extracellular cGMP concentration of $7.3 \mathrm{~nm}$.

Climbing fiber activation with harmaline $(40 \mathrm{mg} / \mathrm{kg}$, i.p.) evoked an immediate, fivefold increase in extracellular cGMP levels (Fig. 1). This was prevented by blockade of voltage-dependent sodium channels, and thus action potentials, by the inclusion of $1 \mu \mathrm{M}$ TTX in the dialysate. TTX had no effect on basal levels of cGMP. Substitution of $\mathrm{Mg}^{2+}$ for $\mathrm{Ca}^{2+}$ in the perfusate also blocked the harmaline-induced increase, without significantly affecting basal cGMP levels (Fig. 1A). Likewise, local application of the $\mathrm{N}$-type $\mathrm{Ca}^{2+}$ channel blocker $\omega$-conotoxin $(100 \mu \mathrm{M})$ had no effect on basal cGMP levels, but attenuated the increase evoked by systemic harmaline (Fig. $1 B$ ). In contrast, local application of nifedipine $(100 \mu \mathrm{M})$, a blocker of L-type $\mathrm{Ca}^{2+}$ channels, greatly potentiated the increase in extracellular cGMP seen following systemic harmaline administration (Fig. $1 B$ ). The harmaline-induced increase in extracellular cGMP levels was also attenuated by a prior lesion of the climbing fibers with the toxin 3-acetylpyridine (Fig. 1C). Histological examination of the inferior olive in these lesioned animals indicated an extensive cell loss; however, there were also many spared neurons, particularly in the medial accessory olive.

Application of methylene blue (1 mM) or LY-83583 (0.1 mM) in the perfusate attenuated the increase in cGMP evoked by harmaline (Fig. 2A). Local application of the general phosphodiesterase inhibitor IBMX (1 $\mathrm{mM})$, or Zaprinast $(10 \mu \mathrm{M})$, a specific inhibitor of type $\mathrm{V}$ phosphodiesterase, potentiated the harmaline-evoked increase in extracellular cGMP (Fig. 2B).

Systemic injection of probenecid $(200 \mathrm{mg} / \mathrm{kg})$, an inhibitor of anion transport systems, had no effect on basal cGMP levels, compared with vehicle (dimethyl sulfoxide, DMSO)-injected rats (Fig. $3 A$ ). However, probenecid dramatically potentiated the increase in extracellular cGMP evoked by harmaline. Similar results were obtained when another inhibitor of anion transport, bromosulfophthalein $(100 \mu \mathrm{M})$, was applied locally via the microdialysis probe (Fig. $3 B$ ).

Inhibitors of $\mathrm{NO}$ synthase blocked the harmaline-induced increase in extracellular cGMP when administered either locally or systemically (Fig. 4). Application of L-NMMA (1 mM) via the microdialysis probe greatly inhibited the harmaline-induced increase in cGMP (Fig. 4A). In contrast, D-NMMA (1 mM) produced only a slight, nonsignificant attenuation of the effect. Local application of NAME (Fig. 4B) or N-Arg (Fig. 4C) dose dependently inhibited the harmaline-induced cGMP increase. Systemic application of N-Arg $(50 \mathrm{mg} / \mathrm{kg})$ also blocked the cGMP increase evoked by harmaline (Fig. 4D). 

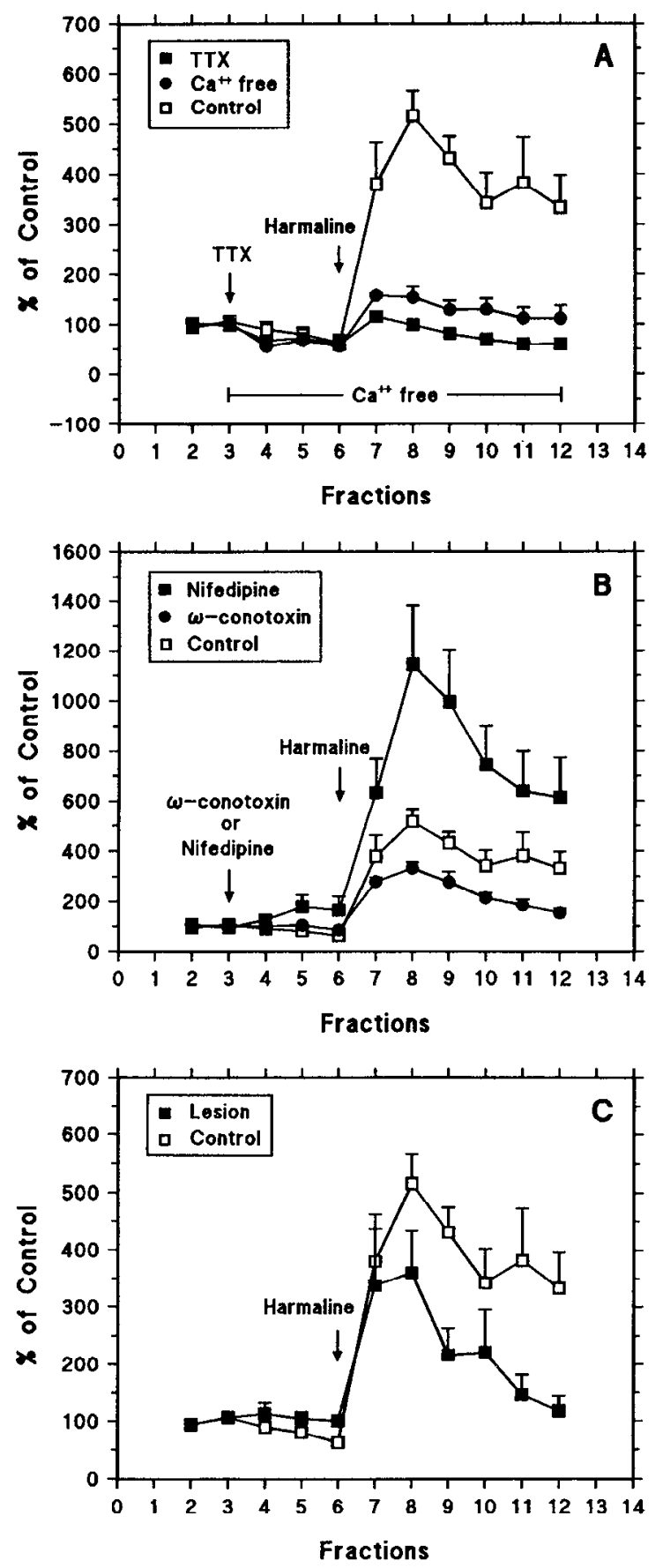

Figure 1. Systemic harmaline administration $(40 \mathrm{mg} / \mathrm{kg}$, i.p.) produces an immediate increase in the extracellular levels of cGMP in the cerebellar cortex. A, Application of artificial CSF containing 1 mM TTX via the microdialysis probe prevented the harmaline-induced increase $(F=87.89 ; p<0.01)$. A similar blockade of the harmaline effect was seen when the ACSF was switched to one in which $\mathrm{Mg}^{2+}$ was substituted for $\mathrm{Ca}^{2+}$ after collection of the first three baseline fractions $(F=56.77$; $p<0.01) . B$, Local application $100 \mu \mathrm{M} \omega$-conotoxin attenuated the effect of harmaline $(F=19.88 ; p<0.01)$, while inclusion of $100 \mu \mathrm{M}$ nifedipine in the microdialysis probe potentiated the harmaline-induced increase in extracellular cGMP levels $(F=16.99 ; p<0.01)$. $C$, Prior treatment with the climbing fiber neurotoxin 3-acetylpyridine also attenuated the harmaline-induced increase in extracellular cGMP levels $(F=18.11 ; p$ $<0.01$ ).

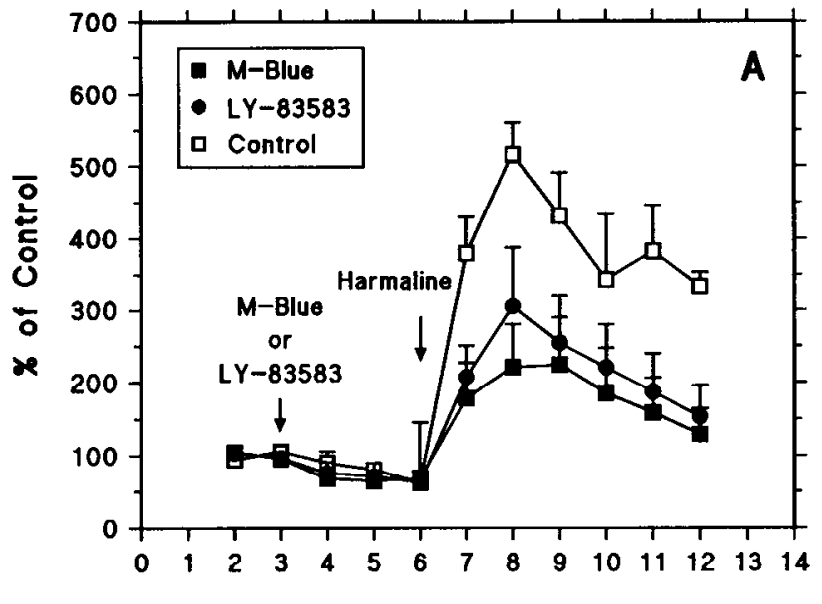

Fractions

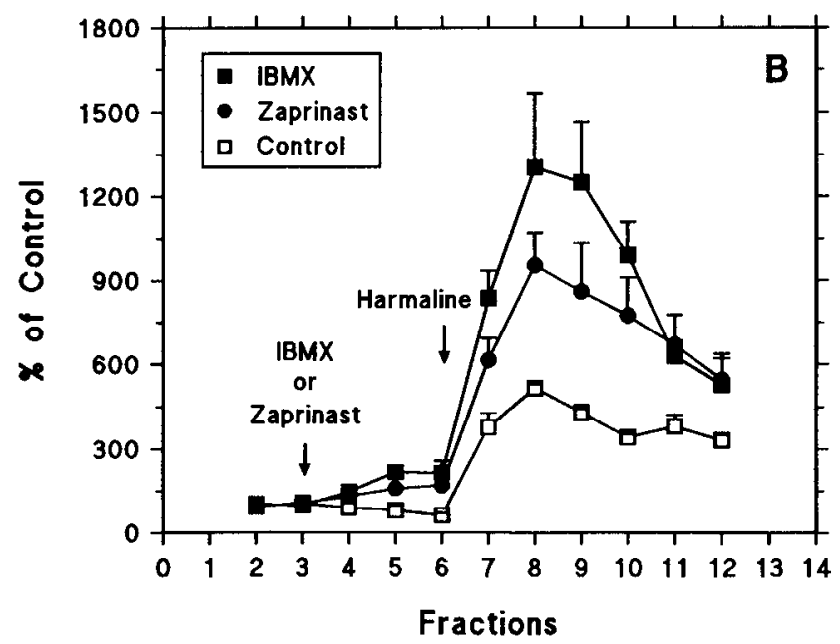

Figure 2. A, The local administration of the guanylyl cyclase inhibitors methylene blue (1 mM) and LY-83583 $(100 \mu \mathrm{M})$ attenuated the cGMP increase produced by systemic harmaline $(40 \mathrm{mg} / \mathrm{kg}$, i.p.) administration $(F=28.47 ; p<0.01$, and $F=15.45 ; p<0.01$, respectively). $B$, The local administration of the general phosphodiesterase inhibitor IBMX $(1 \mathrm{M})$ or the selective inhibitor of type V phosphodiesterase, Zaprinast $(10 \mu \mathrm{M})$, potentiated the increase in cGMP induced by harmaline $(F=$ $37.68 ; p<0.01$, and $F=23,95 ; p<0.01$, respectively).

Local pretreatment with the NMDA receptor antagonist AP5 $(1 \mathrm{mM})$ via the microdialysis probe prevented the harmalineinduced increase in extracellular cGMP (Fig. 5). Pretreatment with the AMPA receptor antagonist CNQX $(100 \mu \mathrm{M})$ also significantly attenuated the response to harmaline (Fig. 5).

Excitatory amino acid agonists evoked large increases in extracellular cGMP when applicd locally via the microdialysis probe (Fig. 6). NMDA (1 mM) produced a massive increase in extracellular cGMP, which was slightly attenuated by the inclusion of TTX $(1 \mu \mathrm{M})$ in the dialysate (Fig. $6 A)$. This NMDAinduced cGMP increase was greatly attenuated and delayed by prior application of AP5 $(1 \mathrm{mM})$. Local AMPA $(100 \mu \mathrm{M})$ application also produced a dramatic increase in extracellular cGMP in the presence of TTX (Fig. 6B). This was unaffected by AP5 ( $1 \mathrm{~mm}$ ) but inhibited by CNQX $(100 \mu \mathrm{M})$. The metabotropic glutamate receptor agonist $t$-ACPD $(100 \mu \mathrm{M})$ also produced a smaller but significant increase in extracellular cGMP in the presence of TTX (Fig. 6C). This was unaffected by AP5 (1 mM). 

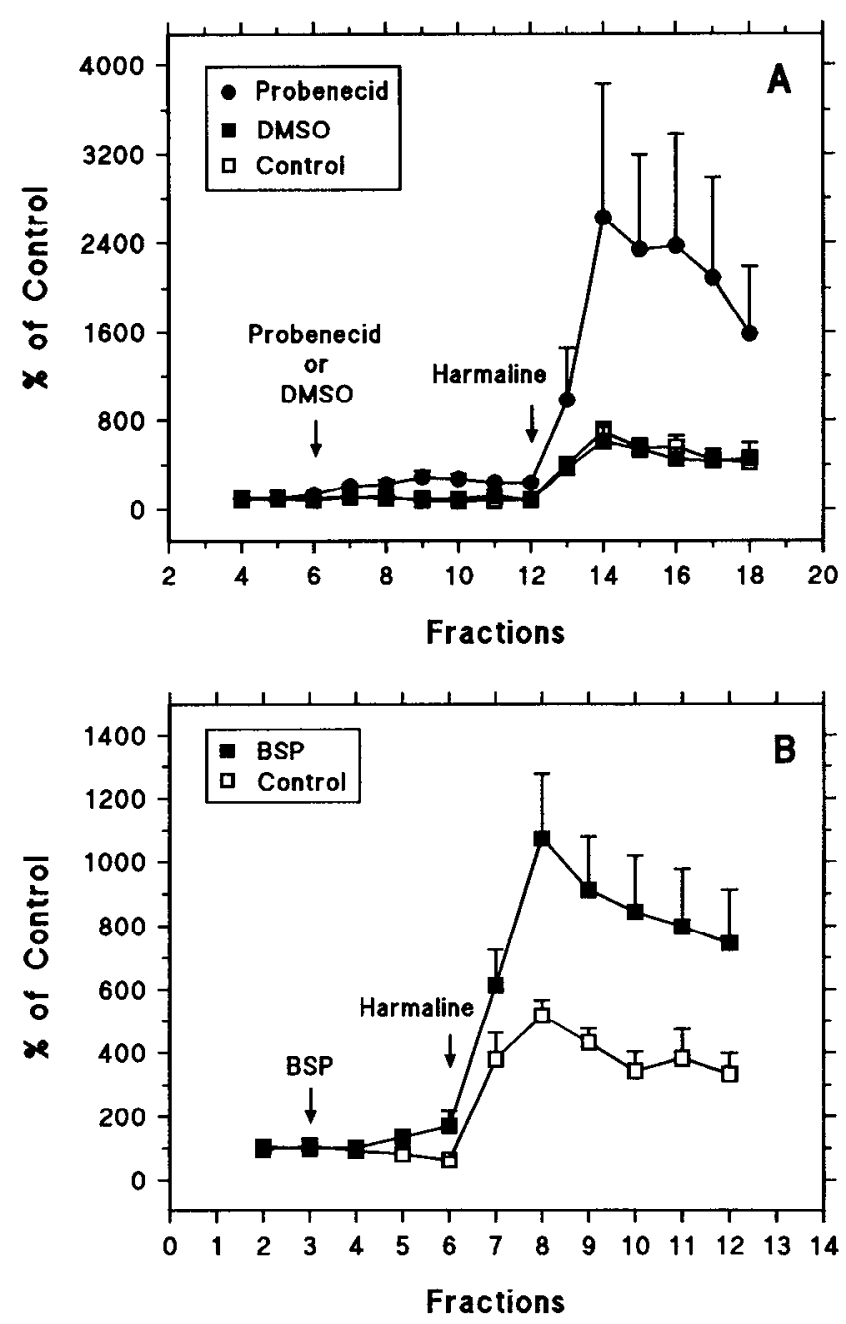

Figure 3. A, The systemic injection of probenecid $(200 \mathrm{mg} / \mathrm{kg})$ potentiated the increase in cGMP following harmaline $(F=11.42 ; p<0.01)$ compared to the control, while vehicle (DMSO) pretreatment had no significant effect. $B$, Locally applied bromosulfophthalein $(B S P ; 100$ $\mu \mathrm{M})$ also potentiated the harmaline-stimulated extracellular CGMP increase $(F=37.33 ; p<0.01)$.

\section{Discussion}

Many studies have examined the pharmacological regulation of cGMP levels in the cerebellar cortex (Wood, 1991). Large changes in cGMP concentration could be demonstrated in response to various drug treatments. Microdissection studies have shown that the molecular layer accounts for about $80 \%$ of the cGMP seen in such studies, with the remaining $20 \%$ arising from the granule cell layer (Rubin and Ferrendelli, 1977). Taking into account the tortuosity and volume fraction of the extracellular space (Nicholson and Phillips, 1981) and the extractive properties of the microdialysis probe (Benveniste and Huttemeier, 1990), it would appear safe to conclude that the changes in extracellular cGMP we have observed derive largely, if not totally, from changes in the molecular layer.

The activation of excitatory amino acid receptors in the cerebellar cortex results in an NO-dependent increase in the production of cGMP (Garthwaite et al., 1988, 1989; Bredt and Snyder, 1989; Wood et al., 1990; Wood, 1991). The alkaloid harmaline selectively activates the climbing fiber input by increasing the firing rate of inferior olive neurons (LaMarre et al.,
1971; Llinas and Volkind, 1973). This is associated with a large increase in cerebellar cGMP levels, apparently in response to increased release of endogenous excitatory amino acids following climbing fiber activation (Guidotti et al., 1975; Biggio et al., 1977; Lorden et al., 1985; Wood et al., 1990). We have found, using the technique of intracerebellar microdialysis in freely moving, unanesthetized rats, that this is associated with a large increase in the extracellular levels of this cyclic nucleotide. This was completely prevented by inclusion of TTX in the perfusion solution, and attenuated by prior lesion of the climbing fibers with 3-acetylpyridine. These results indicate that the harmalineinduced increase in extracellular cGMP was dependent upon climbing fiber activation.

The removal of $\mathrm{Ca}^{2+}$ from the perfusion medium would be expected to block both synaptic transmission and the $\mathrm{Ca}^{2+}$ dependent activation of NO. Thus, it is not surprising that this completely prevented the harmaline-induced increase in extracellular cGMP. $\mathrm{Ca}^{2+}$ does not appear to be directly required in the mechanism responsible for the release of cGMP, since the increase in extracellular cGMP seen in response to the local application of nitroprusside was not prevented by the removal of $\mathrm{Ca}^{3+}$ from the perfusion medium (D. Singla, D. Luo, and S. $\mathrm{R}$. Vincent, unpublished observations).

Local application of $\omega$-conotoxin attenuated the harmalineinduced cGMP increase. This may indicate a role for $\mathrm{N}$-type $\mathrm{Ca}^{2+}$ channels in mediating the release of excitatory transmitters from the climbing fibers (and/or mossy fibers; see below) in the cerebellar cortex. Indeed, a recent report demonstrated that $\omega$-conotoxin decreases potassium-evoked glutamate release from rat cerebellar slices (Dickie and Davies, 1992). In contrast, the L-type $\mathrm{Ca}^{2+}$ channel blocker nifedipine, which does not inhibit potassium-evoked glutamate release from cerebellar slices (Barnes and Davies, 1988), enhanced the increase in cGMP seen in response to harmaline. One way this might arise would be if nifedipine prevented the activation of the $\mathrm{Ca}^{2+} /$ calmodulindependent cGMP phosphodiesterase, which has recently been described in rat brain (Mayer et al., 1992).

The increase in extracellular cGMP induced by harmaline was blocked by a variety of NO synthase inhibitors given locally or systemically. This is consistent with previous in vivo or in vitro work indicating that NO production is an essential step in the pathway leading to cGMP synthesis following excitatory amino acid stimulation in the cerebellar cortex (Bredt and Snyder, 1989; Garthwaite et al., 1989; East and Garthwaite, 1990; Wood et al., 1990; Wood, 1991). Both methylene blue and LY83583 (Schmidt et al., 1985), which have been suggested to inhibit soluble guanylyl cyclase, perhaps via the formation of superoxide anion (Brüne et al., 1990), attenuated the cGMP increase evoked by harmaline, although this effect could also have resulted from direct inhibition of NO synthase by these drugs (Mulsch et al., 1988; Mayer et al., 1993). These data are consistent with the NO-dependent activation of soluble guanylyl cyclase following harmaline administration. Inhibition of phosphodiesterase activity with IBMX, or Zaprinast, dramatically potentiated the response to harmaline. Thus, although phosphodiesterase levels in the cerebellum are very low (Greenberg et al., 1978), the type $\mathrm{V}$ isoform does appear to play an active role in regulating cerebellar cGMP levels. It is not yet known whether CGMP is hydrolyzed before or after being released from the cells in which it is produced.

In this discussion, an attempt will be made to explain our results in terms of what is now known regarding the cellular 

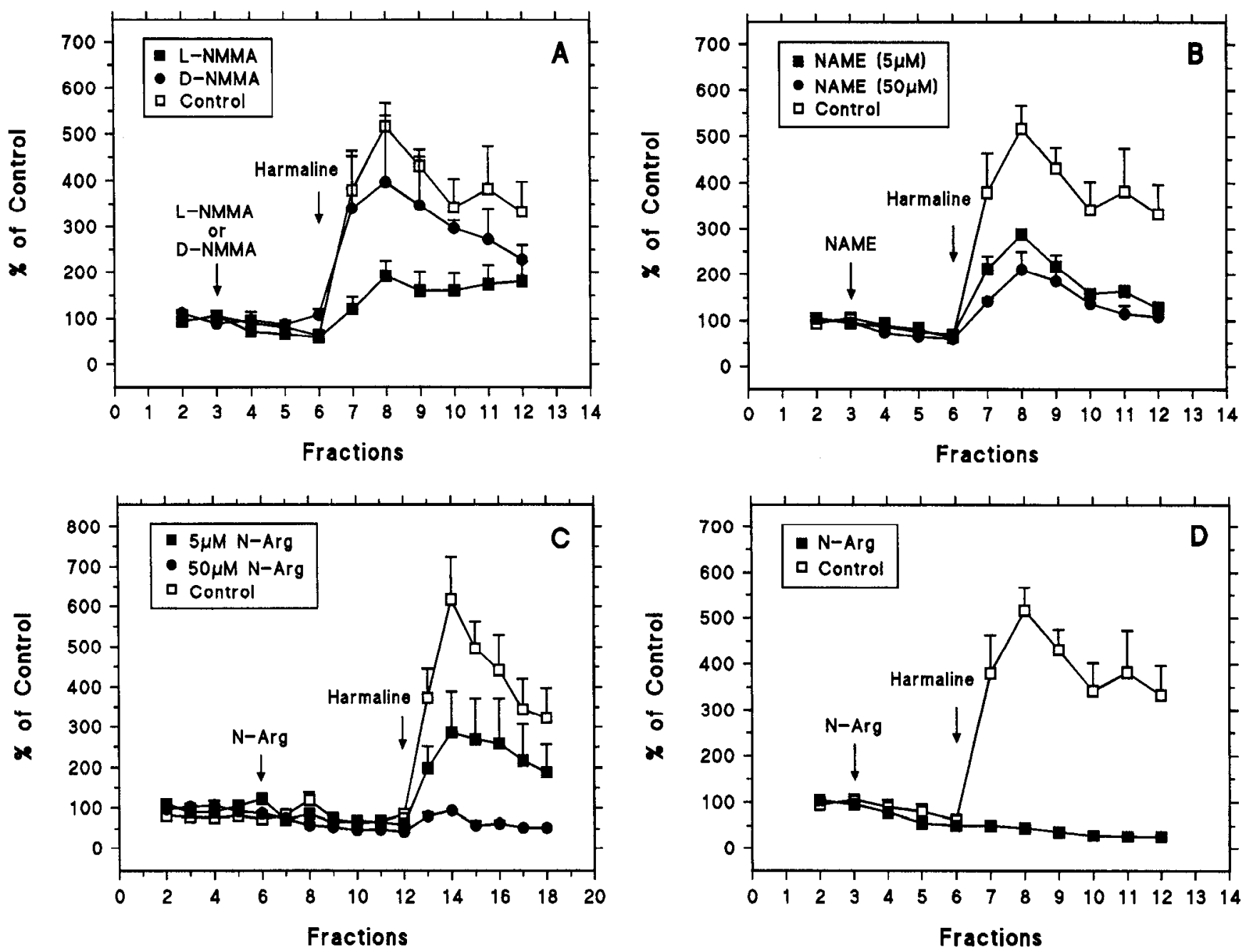

Figure 4. A, Local administration via the microdialysis probe of $1 \mathrm{mM} \mathrm{N} \mathrm{N}^{\mathrm{G}}$-monomethyl-L-arginine $(L-N M M A)$ inhibited the increase in cGMP seen in response to systemic harmaline $\left(40 \mathrm{mg} / \mathrm{kg}\right.$, i.p.) $(F=39.63 ; p<0.01)$, while $1 \mathrm{mM} \mathrm{N}^{\mathrm{G}}$-monomethyl-D-arginine (D-NMMA) was without significant effect. $B$, Local application of $\mathrm{N}^{G}$-nitro-L-arginine methyl ester hydrochloride (NAME) in the microdialysatc at $5 \mu \mathrm{M}(F=33.95 ; p<$ $0.01)$ and $50 \mu \mathrm{M}(F=48.59 ; p<0.01)$ attenuated the harmaline-stimulated cGMP levels. $C$, Local application of NG-nitro-L-arginine (N-Arg) at $5 \mu \mathrm{M}(F=20.96 ; p<0.01)$ and $50 \mu \mathrm{M}(F=123.77 ; p<0.01)$, via the microdialysis probe, attenuated the harmaline-stimulated extracellular cGMP levels. $D$, Systemic administration of N-Arg $(50 \mathrm{mg} / \mathrm{kg}$, i.p.) also blocked the harmaline-stimulated extracellular cGMP increase $(F=115.17$; $p<0.01$ ).

localization of NO synthase and the cGMP system in the cerebellar cortex (Fig. 7). In the rat, the cerebellum has the highest concentration of NO synthase in the brain, and histochemical studies indicate that it is present in granule and basket cells, but not in Purkinje cells or their climbing fiber afferents (Bredt et al., 1990; Vincent and Kimura, 1992). In contrast, soluble guanylyl cyclase has been localized with monoclonal antibodies or in situ hybridization predominantly in the Purkinje cells (Ariano et al., 1982; Nakane et al., 1983; Matsuoka et al., 1992). Monoclonal antibodies to cGMP have also demonstrated intense staining of Purkinje cells (Sakaue et al., 1988). Similarly, high levels of cGMP-dependent protein kinase and its target, G-substrate, are expressed in Purkinje cells (Schlichter et al., 1980; Lohmann et al., 1981). Together, these results point to the Purkinje cells as major targets of cGMP action in the cerebellar cortex.

In cerebellar slices from adult rats, the levels of cGMP can be elevated in a $\mathrm{Ca}^{2+}$-dependent manner by depolarization with elevated potassium (Ferrendelli et al., 1973; Raiteri et al., 1991;
Southam and Garthwaite, 1991). This may be largely mediated by glutamate and/or aspartate release and NMDA receptor activation, since most of the potassium-evoked response could be inhibited by AP5 (Raiteri et al., 1991). Intracisternal injection of AP5 prevents the harmaline-induced increase in cerebellar cGMP levels seen in vivo (Wood et al., 1982). Furthermore, we have found that locally applied AP5 can also block the increase in extracellular cGMP seen following climbing fiber activation. Purkinje cells are the major targets of climbing fibers; however, they lack NMDA receptors (Farrant and Cull-Candy, 1991), and activation of these cells by the climbing fibers appears to be mediated through AMPA receptors. Climbing fiber collaterals activate the deep cerebellar nuclei via both AMPA and NMDA receptors (Llinas and Muhlethaler, 1988; Van der Want et al., 1989; Audinat et al., 1992). The deep cerebellar nuclei, in turn, give rise to mossy fibers that can act on granule cells via both NMDA and AMPA receptors (Garthwaite and Brodbelt, 1989). Furthermore, parallel fibers appear to activate Purkinje cells via AMPA receptors, but can activate inhibitory in- 


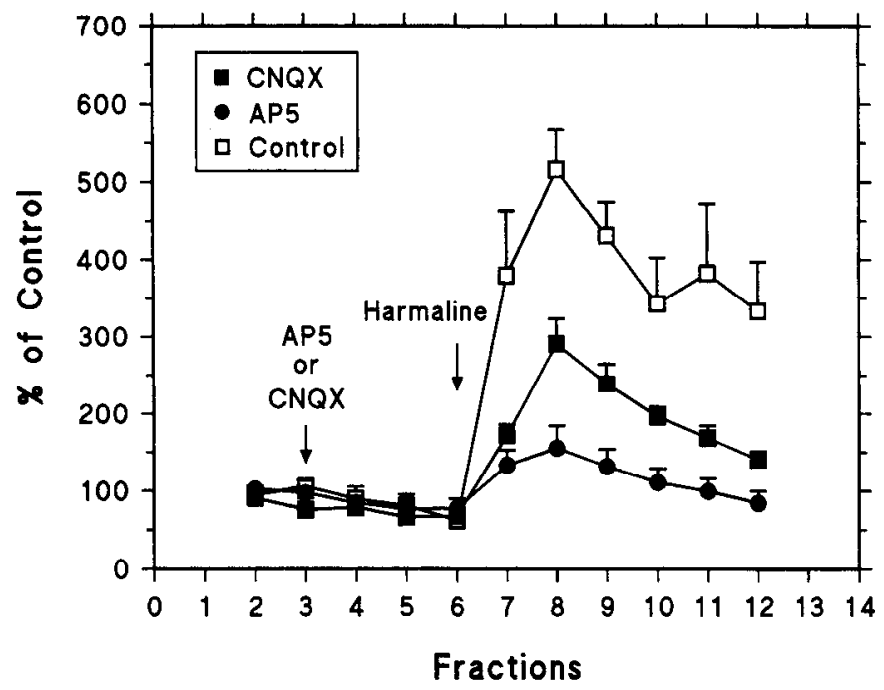

Figure 5. The harmaline-stimulated increase in extracellular cGMP was attenuated by local application of the excitatory amino acid antagonists $1 \mathrm{~mm}$ AP5 $(F=62.5 ; p<0.01)$ and $100 \mu \mathrm{M}$ CNQX $(F=27.14$; $p<0.01)$ via the microdialysis probe.

terneurons, such as basket cells, via both AMPA and NMDA receptors (Hussain et al., 1991). Thus, the increase in cGMP seen following harmaline, or the local infusion of NMDA or AMPA, could be due to activation of granule cells or basket cells, both of which contain NO synthase.

The harmaline-induced increase in cerebellar cGMP levels was also antagonized by direct intracerebellar injection of CNQX (Rao et al., 1990). CNQX also greatly attenuated the increase in extracellular cGMP observed following harmaline. CNQX might inhibit the harmaline-induced elevation in cGMP through actions at both NMDA (Birch et al., 1988) and AMPA receptors. We have found that AMPA can produce a massive, CNQXsensitive, AP5-insensitive increase in extracellular cGMP levels in the presence of TTX. This indicates that AMPA receptor activation can result in NO formation, in the absence of NMDA receptor activation.

Mctabotropic glutamatc rcceptor stimulation can also produce an NO-dependent increase in cGMP levels in cerebellar slices from adult rats (Okada, 1992). This appears to be due to NO synthase activation following the release of $\mathrm{Ca}^{2+}$ from intracellular stores (Okada, 1992). We have found that local application of the metabotropic agonist $t$-ACPD can induce an increase in extracellular cGMP levels when both action potentials and NMDA receptors are blocked. This suggests a direct action of $t$-ACPD on NO synthase-containing cells. The granule cells are likely targets, since they contain NO synthase and possess metabotropic glutamate receptors (Nicoletti et al., 1986; Fagni et al., 1991; East and Garthwaite, 1992).

The local application of NMDA, AMPA, or $t$-ACPD produced an increase in extracellular cGMP, even in the presence of TTX. This suggests that activation of NO synthase in granule and/or basket cells can occur in the absence of cell firing. However, TTX did attenuate the increase in cGMP seen following local NMDA application. This probably reflects the activation

Figure 6. A, The local application of the excitatory amino acid agonist NMDA (1 mM) in the dialysate produced a large increase in extracellular
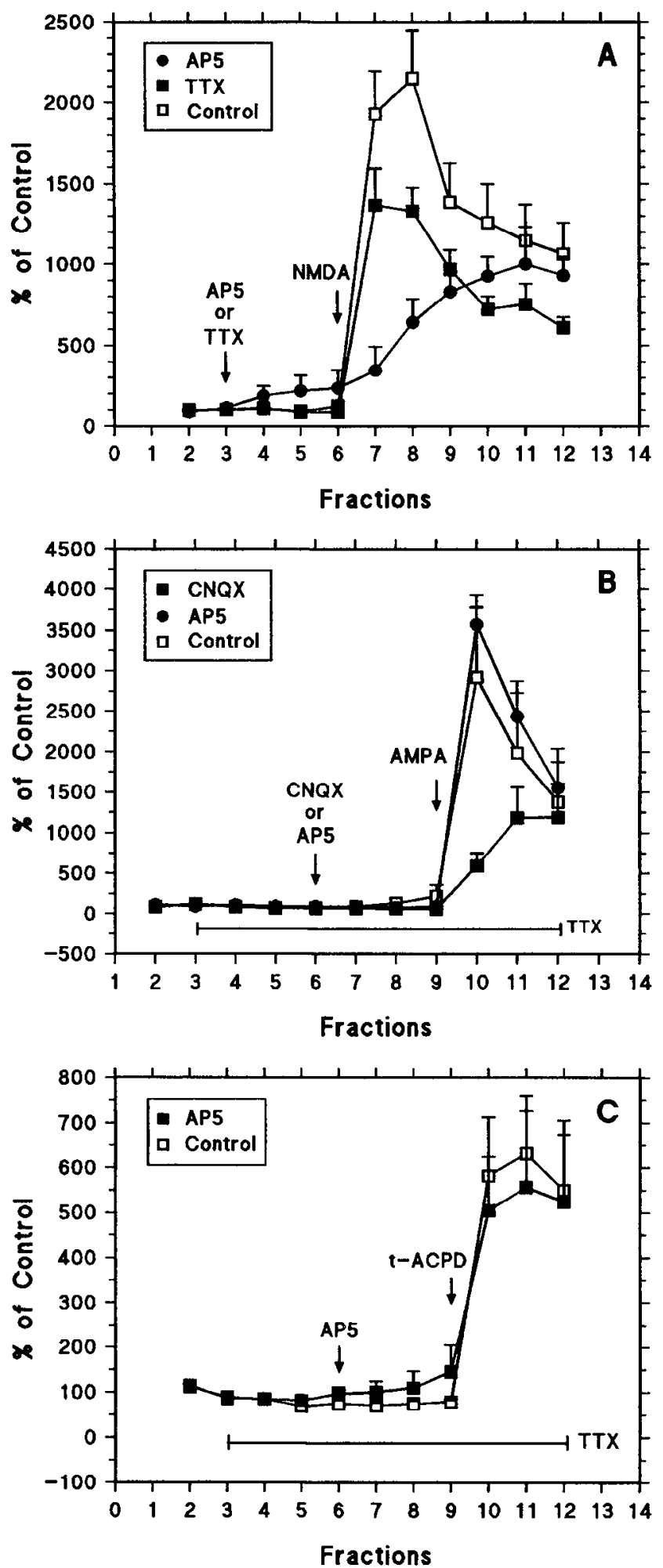

cGMP. This was somewhat attenuated by the inclusion of $1 \mu \mathrm{M}$ TTX $(F=17.84 ; p<0.01)$ and reduced and delayed by inclusion of $1 \mathrm{mM}$ AP5 $(F=30.57 ; p<0.01)$ in the dialysate. $B$, The local application of the excitatory amino acid agonist AMPA $(100 \mu \mathrm{M})$ via the microdialysis probe dramatically increased extracellular cGMP levels in the presence of $1 \mu \mathrm{M}$ TTX. This was unaffected by $1 \mathrm{~mm}$ AP5, but markedly attenuated by $100 \mu \mathrm{M}$ CNQX $(F=6.27 ; p<0.05)$. $C$, The local application of the metabotropic receptor agonist $t$-ACPD $(100 \mu \mathrm{M})$ via the microdialysis probe increased the extracellular level of cGMP in the presence of TTX. This was unaffected by local pretreatment with 1 mM AP5. 


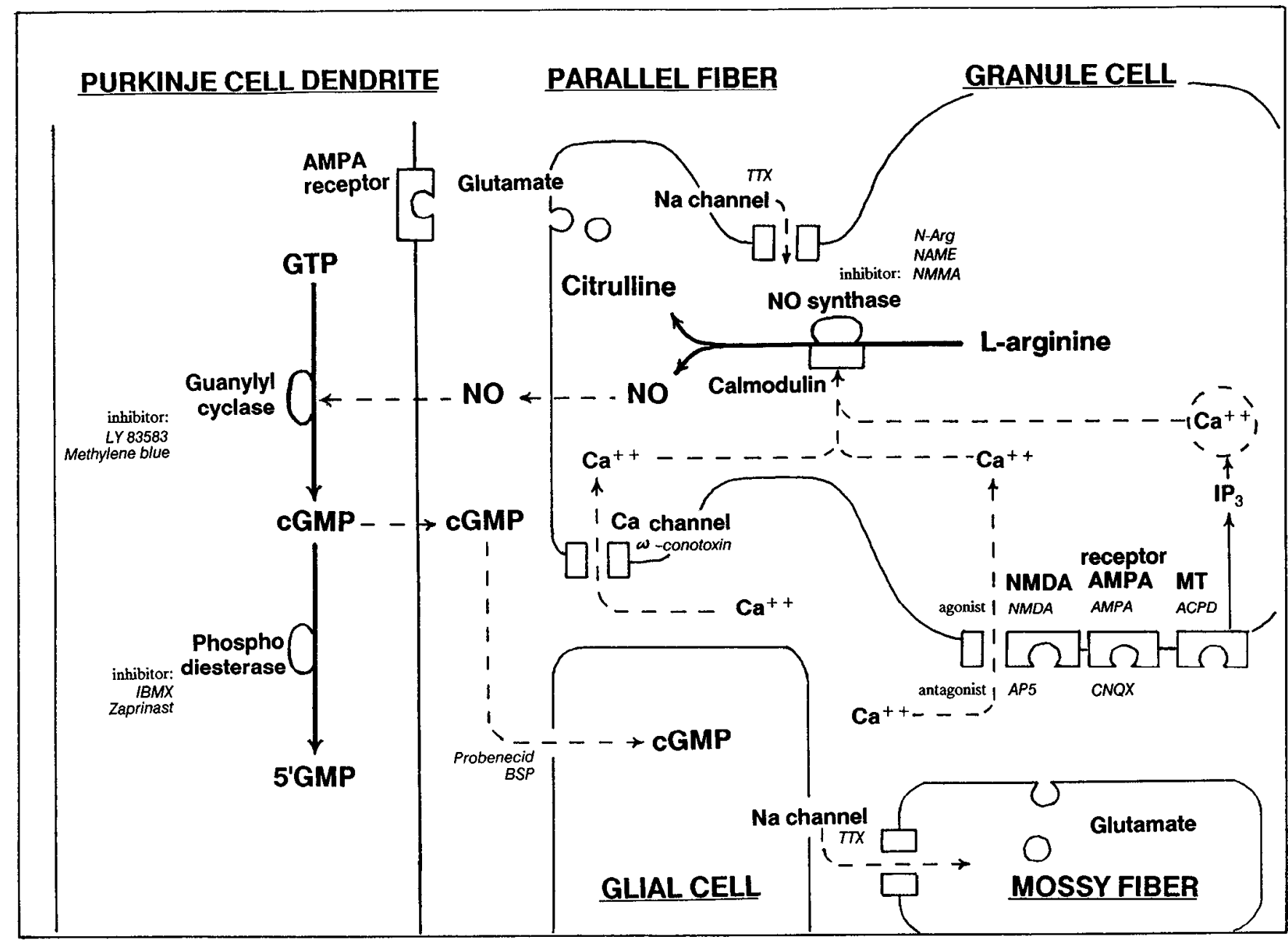

Figure 7. A diagram illustrating the proposed sites of action of the various drugs affecting the extracellular levels of cGMP in the cerebellar cortex. Harmaline-induced activation of the inferior olive activates mossy fibers arising in the deep cerebellar nuclei, resulting in glutamate release onto granule cells. This can activate NO synthase in these neurons via NMDA, AMPA, or metabotropic $(M T)$ receptors. NO produced in granule cells or in basket cells following their activation by parallel fibers (not shown) can diffuse into Purkinje cells to activate soluble guanylyl cyclase. This results in an elevation of cGMP levels, and an efflux of cGMP. The released cGMP may then be accumulated in adjacent glial elements via a probenicid-sensitive carrier.

of presynaptic NO synthase in granule and/or basket cell nerve terminals following action potential invasion.

Normal human CSF has been reported to contain 2 nM cGMP (Trabucchi et al., 1977). In the present study, the basal extracellular cGMP level in the cerebellar cortex was estimated to be about 7 nM. This would correspond to about $1-5 \%$ of the tissue concentration of cGMP in the adult rat cerebellar cortex (Lorden et al., 1985; De Vente and Steinbusch, 1992). The extracellular cGMP concentration was raised immediately following harmaline treatment to about $35 \mathrm{~nm}$. In the presence of probenecid, the extracellular levels increased 30 -fold, to over $200 \mathrm{~nm}$ in response to harmaline. This suggests that released cGMP is normally actively removed from the extracellular space into a probenecid-sensitive compartment. Indeed, the highest levels of a high-affinity cyclic nucleotide uptake system, which can accumulate cAMP or cGMP, occur in the cerebellum (Johnston and Balcar, 1973).

The efflux of cAMP from the CSF appears to be mediated via a probenecid-sensitive organic anion carrier (see Cramer, 1977). Henderson and Tsuji (1987) have demonstrated that cAMP efflux from some cells occurs via a bromosulfophthalein- sensitive, large anion carrier, which may correspond to a multidrug resistance transporter. We have found that probenecid or bromosulfophthalein augment the increase in extracellular cGMP produced by harmaline. Probenecid also increases the extracellular levels of the acid metabolites of monoamine neurotransmitters in microdialysis experiments (Miyamoto et al., 1991). This suggests that the mechanism mediating the extrusion of cGMP and other organic anions from neurons differs from the probenecid-sensitive system mediating their removal from the extracellular space. It is possible that cGMP released from neurons is taken up into adjacent glial elements via a probenecid-sensitive carrier. Such a process might account for the immunohistochemical data indicating that, although guanylyl cyclase appears to be largely neuronal (Biggio et al., 1978; Ariano et al., 1982; Nakane et al., 1983; Matsuoka et al., 1992), cGMP accumulation occurs in cerebellar glial cells (De Vente and Steinbusch, 1992; Southam et al., 1992).

The functional significance of cAMP efflux in the brain has recently been discussed (Rosenberg, 1992). The efflux of cyclic nucleotides may simply be a means of regulating the intracellular levels of these molecules. Indeed, the increased cGMP produc- 
tion seen in pancreatic acinar cells following muscarinic or peptide stimulation is followed by a large increase in cGMP secretion. This appears to be responsible for restoring tissue cGMP levels to their basal state (Kapoor and Krishna, 1977). A similar phenomenon may occur in other tissues (O'Dea et al., 1978; Tjörnhammar et al., 1983; Schini et al., 1988, 1989; Burton et al., 1990; Billiar et al., 1992; Heuze-Joubert et al., 1992). However, extracellular actions of cGMP are also a possibility. In Dictyostelium discoideum cAMP acts as a chemoattractant via an action on cell surface receptors (Janssens and Van Haastert, 1987). Recent evidence indicates that receptors for cAMP on mammalian myocytes may be involved in the regulation of cardiac sodium channels through a $G$-protein-dependent mechanism (Sorbera and Morad, 1991). There are reports that extracellular application of cGMP can affect the electrical properties of various neurons (Phillis et al., 1974; Stone et al., 1975), including Purkinje cells (Hoffer et al., 1971; Siggins et al., 1976). Thus, the release of cGMP may indicate a role for this cyclic nucleotide in intercellular communication in the cerebellar cortex.

\section{References}

Ariano MA, Lewicki JA, Brandwein JH, Murad F (1982) Immunohistochemical localization of guanylate cyclase within neurons of rat brain. Proc Natl Acad Sci USA 79:1316-1320.

Audinat E, Gahwiler HG, Knopfel T (1992) Excitatory synaptic potentials in neurons of the deep nuclei in olivo-cerebellar slice cultures. Neuroscience 49:903-911.

Barber R, Butcher RW (1983) The egress of cyclic AMP from metazoan cells. In: Advances in cyclic nucleotide research, Vol 15 (Greengard P, Robinson GA, eds), pp 119-138. New York: Raven.

Barnes S, Davies JA (1988) The effects of calcium channel agonists and antagonists on the release of endogenous glutamate from cerebellar slices. Neurosci Lett 92:58-63.

Benveniste H, Huttemeier PC (1990) Microdialysis-theory and application. Prog Neurobiol 35:195-215.

Biggio G, Brodie BB, Costa E, Guidotti A (1977) Mechanisms by which diazepam, muscimol, and other drugs change the content of cGMP in cerebellar cortex. Proc Natl Acad Sci USA 74:3592-3596.

Biggio G, Corda MG, Casu M, Salis M, Gessa GL (1978) Disappearance of cerebellar cyclic GMP induced by kainic acid. Brain Res 154: 203-208.

Billiar TR, Curran RD, Harbrecht BG, Stadler J, Williams DL, Ochoa JB, Di Silvio M, Simmons RL, Murray SA (1992) Association between synthesis and release of cGMP and nitric oxide biosynthesis by hepatocytes. Am J Physiol 262:C1077-C1082.

Birch PJ, Grossman CJ, Hayes AG (1988) 6,7-Dinitro-quinoxaline2,3-dion and 6-nitro,7-cyano-quinoxaline-2,3-dion antagonize responses to NMDA in the rat spinal cord via an action at the strychnine-insensitive glycine receptor. Eur J Pharmacol 156:177-180.

Brandt MA, Conrad KP (1991) In vivo and in vitro studies of a putative inhibitor of cyclic guanosine $3^{\prime}, 5^{\prime}$-monophosphate production. Proc Soc Exp Biol Med 196:30-35.

Bredt DS, Snyder SH (1989) Nitric oxide mediates glutamate-linked enhancement of cGMP levels in the cerebellum. Proc Natl Acad Sci USA 86:9030-9033.

Bredt DS, Hwang PM, Snyder SH (1990) Localization of nitric oxide synthase indicating a neural role for nitric oxide. Nature 347:768770.

Brüne B, Schmidt K-U, Ullrich V (1990) Activation of soluble guanylate cyclase by carbon monoxide and inhibition by superoxide anion. Eur J Biochem 192:683-688.

Burton GA, MacNeil S, de Jonge A, Haylor J (1990) Cyclic GMP release and vasodilation induced by EDRF and atrial natriuretic factor in the isolated perfused kidney of the rat. $\mathrm{Br} \mathrm{J}$-Pharmacol 99:364368.

Cramer H (1977) Cyclic 3',5'-nucleotides in extracellular fluids of neural systems. J Neurosci Res 3:241-246.

Davoren PR, Sutherland EW (1963) The effect of L-epinephrine and other agents on the synthesis and release of adenosine 3 ' -5 '-phosphate by whole pigeon erythrocytes. J Biol Chem 238:3009-3015.
De Vente J, Steinbusch HWM (1992) On the stimulation of soluble and particulate guanylate cyclase in the rat brain and the involvement of nitric oxide as studied by cGMP immunocytochemistry. Acta Histochem 92:13-38.

Dickie BGM, Davies JA (1992) Calcium channel blocking agents and potassium-stimulated release of glutamate from cerebellar slices. Eur J Pharmacol 229:97-99.

East SJ, Garthwaite J (1990) Nanomolar $\mathrm{N}^{\mathrm{G}}$-nitroarginine inhibits NMDA-induced cyclic GMP formation in rat cerebellum. Eur J Pharmacol 184:311-313.

East SJ, Garthwaite J (1992) Actions of a metabotropic glutamate receptor agonist in immature and adult rat cerebellum. Eur J Pharmacol 219:395-400.

Fagni L, Bossu JL, Bockaert J (1991) Activation of a large-conductance $\mathrm{Ca}^{2+}$-dependent $\mathrm{K}^{+}$channel by stimulation of glutamate phosphoinositide-coupled receptors in cultured cerebellar granule cells. Eur $\mathbf{J}$ Neurosci 3:788-796.

Farrant M, Cull-Candy SG (1991) Excitatory amino acid receptorchannels in Purkinje cells in thin cerebellar slices. Proc R Soc Lond [Biol] 244:179-184.

Ferrendelli JA, Kinscherf DA, Chang MM (1973) Regulation of levels of guanosine cyclic 3',5'-monophosphate in the central nervous system: effects of depolarizing agents. Mol Pharmacol 9:445-454.

Garthwaite J (1991) Glutamate, nitric oxide and cell-cell signalling in the nervous system. Trends Neurosci 14:60-67.

Garthwaite J, Brodbelt AR (1989) Glutamate as the principal mossy fibre transmitter in rat cerebellum: pharmacological evidence. Eur J Neurosci 2:177-180.

Garthwaite J, Charles SL, Chess-Williams R (1988) Endotheliumderived relaxing factor release on activation of NMDA receptors suggests role as intercellular messenger in the brain. Nature 336:385388.

Garthwaite J, Garthwaite G, Palmer RMJ, Salvador M (1989) NMDA receptor activation induces nitric oxide synthesis from arginine in rat brain slices. Eur J Pharmacol 172:413-416.

Greenberg LH, Troyer E, Ferrendelli JA, Weiss B (1978) Enzymatic regulation of the concentration of cyclic GMP in mouse brain. Neuropharmacology 17:737-745.

Guidotti A, Biggio G, Costa E (1975) 3-Acetylpyridine: a tool to inhibit the tremor and the increase of cGMP content in cerebellar cortex elicited by harmaline. Brain Res 96:201-205.

Henderson GB, Tsuji JM (1987) Methotrexate efflux in L1210 cells: kinetic and specificity properties of the efflux system sensitive to bromosulfophthalein and its possible identity with a system which mediates the efflux of $3^{\prime}, 5^{\prime}$-cAMP. J Biol Chem 262:13571-13578.

Heuze-Joubert I, Mennecier P, Simonet S, Laubie M, Verbeuren TJ (1992) Effect of vasodilators, including nitric oxide, on the release of cGMP and cAMP in the isolated perfused rat kidney. Eur J Pharmacol 220:161-171.

Hoffer BJ, Siggins GR, Oliver AP, Bloom FE (1971) Cyclic AMP mediation of norepinephrine synaptic inhibition in rat cerebellar cortex: a unique class of synaptic responses. Ann NY Acad Sci 185:531549.

Hussain S, Gardner CR, Bagust J, Walker RJ (1991) Receptor subtypes involved in responses of Purkinje cell to exogenous excitatory amino acids and local electrical stimulation in cerebellar slices in the rat. Neuropharmacology 30:1029-1037.

Janssens PMW, Van Haastert PJM (1987) Molecular basis of transmembrane signal transduction in Dictyostelium discoideum. Microbiol Rev 51:396-418.

Johnston GAR, Balcar VJ (1973) High affinity uptake of cyclic AMP in rat brain slices. Brain Res 59:451-453.

Kakiuchi S, Rall TW (1968) The influence of chemical agents on the accumulation of adenosine $3^{\prime}, 5^{\prime}$-phosphate in slices of rabbit cerebellum. Mol Pharmacol 4:367-378.

Kapoor CL, Krishna G (1977) Hormone-induced cyclic guanosine monophosphate secretion from guinea pig pancreatic lobules. Science 196:1003-1005.

LaMarre Y, de Montigny C, Dumont M, Weiss M (1971) Harmalineinduced rhythmic activity of cerebellar and lower brainstem neurons. Brain Res 32:246-250.

Llinas R, Muhlethaler M (1988) Electrophysiology of guinea-pig cerebellar nuclear cells in the in vitro brain stem-cerebellar preparation. J Physiol (Lond) 404:241-258.

Llinas R, Volkind RA (1973) The olivo-cerebellar system: functional 
properties as revealed by harmaline-induced tremor. Exp Brain Res 18:69-87.

Llinas R, Walton K, Hillman D, Sotelo C (1975) Inferior olive: its role in motor learning. Science 190:1230-1231.

Lohmann SM, Walter U, Miller PE, Greengard P, De Camilli P (1981) Immunohistochemical localization of cyclic GMP-dependent protein kinase in mammalian brain. Proc Natl Acad Sci USA 78:653-657.

Lorden JF, Oltmans GA, McKwon TW, Lutes J, Beales M (1985) Decreased cerebellar 3' $5^{\prime}$-cyclic guanosine monophosphate levels and insensitivity to harmaline in the genetically dystonic rat (dt). J Neurosci 5:2618-2625.

Matsuoka I, Giuili G, Poyard M, Stengel D, Parma J, Guellaen G, Hanoune $\mathbf{J}$ (1992) Localization of adenylyl and guanylyl cyclase in rat brain by in situ hybridization: comparison with calmodulin mRNA distribution. J Neurosci 12:3350-3360.

Mayer B, Klatt P, Bohme E, Schmidt K (1992) Regulation of neuronal nitric oxide and cyclic GMP formation by $\mathrm{Ca}^{2+}$. J Neurochem 59: 2024-2029.

Mayer B, Brunner F, Schmidt K (1993) Inhibition of nitric oxide synthase by methylene blue. Biochem Pharmacol 45:367-374.

Miyamoto JK, Uezu E, Terashima S-I (1991) Activc transport pumps of HVA and DOPAC in dopaminergic nerve terminals. Physiol Pharmacol 49:141-147.

Mulsch A, Busse R, Liebau S, Forstermann U (1988) LY83583 interferes with the release of endothelium-derived relaxing factor and inhibits soluble guanylyl cyclase. J Pharmacol Exp Ther 247:283288.

Nakane M, Ichikawa M, Deguchi T (1983) Light and electron microscopic demonstration of guanylate cyclase in rat brain. Brain Res 273: 9-15.

Nicholson C, Phillips JM (1981) Ion diffusion modified by tortuosity and volume fraction in the extracellular microenvironment of the rat cerebellum. J Physiol (Lond) 321:225-257.

Nicoletti F, Wroblewski JT, Novelli A, Guidotti A, Costa E (1986) The activation of inositol phospholipid metabolism as a signal-transducing system for excitatory amino acids in primary cultures of cerebellar granule cells. J Neurosci 6:1905-1911.

O'Dea RF, Gagnon C, Zatz M (1978) Regulation of guanosine 3',5'cyclic monophosphate in the rat pineal and posterior pituitary glands. J Neurochem 31:733-738.

Okada D (1992) Two pathways of cyclic GMP production through glutamate receptor-mediated nitric oxide synthesis. J Neurochem 59: 1203-1210.

Phillis JW, Kostopoulos GK, Limacher JJ (1974) Depression of corticospinal cells by various purines and pyrimidines. Can J Physiol Pharmacol 52:1226-1229.

Raiteri M, Maura G, Barzizza A (1991) Activation of presynaptic 5-hydroxytryptamine,-like receptors on glutamatergic terminals inhibits $N$-methyl-D-aspartate-induced cyclic GMP production in rat cerebellar slices. J Pharmacol Exp Ther 257:1184-1188.

Rao TS, Cler JA, Mick SJ, Emmett MR, Iyengar S, Wood PL (1990) 6,7-Dinitroquinoxaline-2,3-dione and 6-nitro, 7-cyanoquinoxaline-2,3dione antagonize responses mediated by $N$-methyl-D-aspartate and NMDA-associated glycine recognition sites in vivo: measurements of cerebellar cyclic-GMP. Neuropharmacology 29:1031-1035.

Rosenberg PA (1992) Functional significance of cyclic AMP secretion in cerebral cortex. Brain Res Bull 29:315-318.

Rubin EH, Ferrendelli JA (1977) Distribution and regulation of cyclic nucleotide levels in cerebellum in vivo. J Neurochem 29:43-51.
Sakaue M, Kuno T, Tanaka C (1988) Novel type of monoclonal antibodies against cyclic GMP and application to immunocytochemistry of the rat brain. Jpn J Pharmacol 48:47-56.

Schini V, Grant NJ, Miller RC, Takeda K (1988) Morphological characterization of cultured bovine aortic endothelial cells and the effects of atriopeptin II and sodium nitroprusside on cellular and extracellular accumulation of cyclic GMP. Eur J Ccll Biol 47:53-61.

Schini V, Schoeffer P, Miller RC (1989) Effect of endothelium on basal and on stimulated accumulation and efflux of cyclic GMP in rat isolated aorta. Br J Pharmacol 97:853-865.

Schlichter DJ, Detre JA, Aswad DW, Chehrazi B, Greengard P (1980) Localization of cyclic GMP-dependent protein kinase and substrate in mammalian cerebellum. Proc Natl Acad Sci USA 77:5537-5541.

Schmidt MJ, Sawyer BD, Truex LL, Marshall WS, Fleisch JH (1985) LY83583: an agent that lowers intracellular levels of cyclic guanosine 3',5'-monophosphate. J Pharmacol Exp Ther 232:764-769.

Schuller F, Fleming I, Stoclet J-C, Gray GA (1992) Effect of endotoxin on circulating cyclic GMP in the rat. Eur J Pharmacol 212:93-96.

Siggins GR, Henriksen SJ, Landis SC (1976) Electrophysiology of Purkinje neurons in the weaver mouse: iontophoresis of neurotransmitters and cyclic nuclcotides, and stimulation of the nucleus locus coeruleus. Brain Res 114:53-69.

Sorbera LA, Morad M (1991) Modulation of cardiac sodium channels by cAMP receptors on the myocyte surface. Science 253:1286-1289.

Southam E, Garthwaite J (1991) Climbing fibres as a source of nitric oxide in the cerebellum. Eur J Neurosci 3:379-382.

Southam E, Morris R, Garthwaite J (1992) Sources and targets of nitric oxide in rat cerebellum. Neurosci Lett 137:241-244.

Stone TW, Taylor DA, Bloom FE (1975) Cyclic AMP and cyclic GMP may mediate opposite neuronal responses in the rat cerebral cortex. Science 187:845-847.

Tjörnhammar M-L, Lazardis G, Bartfai T (1983) Cyclic GMP efflux from liver slices. J Biol Chem 258:6882-6886.

Tjörnhammar M-L, Lazardis G, Bartfai T (1986) Efflux of cyclic guanosinc $3^{\prime}, 5^{\prime}$-monophosphatc from ccrcbcllar slices stimulated by L-glutamate or high $\mathrm{K}^{+}$or $N$-methyl- $N^{\prime}$-nitro- $N$-nitrosoguanidine. Neurosci Lett 68:95-99.

Trabucchi M, Cerri C, Spano PF, Kumakura K (1977) Guanosine $3^{\prime}, 5^{\prime}$-monophosphate in the CSF of neurological patients. Arch Neurol 34:12-13.

Van der Want JJL, Wiklund L, Guegan M, Ruigrok T, Voogd J (1989) Anterograde tracing of the rat olivocerebellar system with Phaseolus vulgaris leucoagglutinin (PHA-L). Demonstration of climbing fiber collateral innervation of the cerebellar nuclei. J Comp Neurol 288: $1-18$.

Vincent SR, Hope BT (1992) Neurons that say NO. Trends Neurosei 15:108-113.

Vincent SR, Kimura H (1992) Histochemical mapping of nitric oxide synthase in the rat brain. Neuroscience 46:755-784.

Wood PL (1991) Pharmacology of the second messenger, cyclic guanosine $3^{\prime}, 5^{\prime}$-monophosphate, in the cerebellum. Pharmacol Rev 43: $1-25$.

Wood PL, Richard JW, Pilapil C, Nair NPV (1982) Antagonists of excitatory amino acids and cyclic guanosine monophosphate in cerebellum. Neuropharmacology 21:1235-1238.

Wood PL, Emmett MR, Rao TS, Cler J, Mick S, Iyengar S (1990) Inhibition of nitric oxide synthase blocks $N$-methyl-D-aspartatequisqualate-, kainate-, harmaline-, and pentylenetetrazole-dependent increases in cerebellar cyclic GMP in vivo. J Neurochem 55:346-348. 